\title{
A REVIEW OF SHIPOWNERS' STATUTORY DUTY UNDER SECTION 905(b) OF THE LONGSHOREMEN'S AND HARBORWORKERS' COMPENSATION ACT: DOES SCINDIA REQUIRE A CHANGE IN COURSE?
}

In the wake of the 1972 amendments' to the Longshoremen's and Harbor Workers' Compensation Act ${ }^{2}$ (LHWCA), many courts and commentators have wrestled with the problem of defining the standard of care applicable in negligence actions arising under section 905(b) of the Act. ${ }^{3}$ The Supreme Court's recent decision in Scindia Steam Navigation Co. v. De Los Santos ${ }^{4}$ defined the standard of care owed to longshoremen by shipowners and stevedores; lowever, the Court's analysis was unclear as to the effect of a shipowner's breach of a duty imposed by statute or regulation in section $905(\mathrm{~b})$ actions. 5 The result 1980)).

1. Pub. L. No. 92-576, 86 Stat. 1251 (amending 33 U.S.C. $\$ 901-950$ (1976 \& Supp. IV

2. 33 U.S.C. $\$ \$ 901-950$ (1976). Section $905(b)$, enacted in 1972, permits an injured longshoreman to recover damages "caused by the negligence of a vessel" and provides that the stevedoring company "shall not be liable to the vessel for such damages directly or indirectly and any agreements or warranties to the contrary shall be void." Section 905 (b) also provides that the "liability of the vessel . . . shall not be based upon the warranty of seaworthiness or a breach thereof at the time the injury occured." Id.

3. See generally G. Gilmore \& C. Black, ThE Law of AdMiralty, 449.55 (2d ed. 1975); George, The Content of the Negligence Action by Longshoremen against Shipowners Under the 1972 Amendments to the Longshoremen [sic] and Harbor Workers' Compensation Act, 11 J. MAR. L. \& CoM. 1 (1979); Gonnan, The Longshoremen's and Harbor Workers' Compensation Act-Afrer the 1972 Amendments, 6 J. MAR. L. \& CoM. 1 (1974); Hazen \& Toriello, Longshoremen's Personal Injury Actions Under the 1972 Amendments to the Longshoremen's and Harbor Workers" Compensation Act, 53 ST. JoHN's L. REv. I (1978); Robertson, Negligence Actions by Longshoremen Against Shipowners Under the 1972 Amendments to the Longshoremen's and Harbor Workers' Compensation Act, 7 J. MAR. L. 447 (1976); Comment, Developing A Consistent Theory of Vessel Liability to Injured Longshoremen Under the LHWCA, 45 BROOKLYN L. REV. 731 (1979); Comment, Shipowner's Duties and Apportionment of Liability Under The Longshoremen's and Harbor Workers' Compensation Act, 40 FordhaM L. REv. 323 (1978); Comment, Shipowner Liability Under Section 905(b) of the Longshoremen's and Harbor Workers' Compensation Act: A Proposed Standard of Care, 9 FoRDHAM URB. L.J. 323 (1980); Note, The Injured Longshoreman vs. The Shipowner After 1972: Business Invitees, Land-Based Standards, and Assumption of the Risk, 28 Hastings L.J. 771 (1977); Note, Duty Owed by Shipowner Under 1972 Amendments to Longshoremen's Act is that of Land Based Premises Owner to Business Invitee, 6 J. MAR. L. \& CoM. 643 (1975); Comment, The Vessel Owmer's Standard of Care Under the 1972 Amendments to the Longshoremen's and Harbor Workers' Compensation Act, 23 LoY. L. REv. 986 (1977).

4. 451 U.S. 156 (1981).

5. Id. at 176-78. See infra text accompanying notes $24-32$ \& $105-09$. 
has been confusion among the lower federal courts. ${ }^{6}$

In an effort to remedy this confusion, this note reviews the 1972 amendments to the LHWCA ${ }^{7}$ and discusses the Scindia Court's interpretation of those amendments in hight of the various legislative schemes that impose statutory duties on vessel owners. ${ }^{8}$ After examining the varied approaches of the federal appellate courts in section 905(b) cases involving statutory violations before Scindia, 9 the note concludes that Scindia did not modify the law as set forth in those prior appellate decisions. Any modification would be both unnecessary and contrary to Congress' intent in enacting the 1972 amendments. ${ }^{10}$

\section{Statutory Duty In Light of the 1972 Amendments TO THE LHWCA}

\section{A. The Background of the Amendments.}

Prior to the 1972 amendments to the Act, ${ }^{11}$ a plamtiff longshoreman prevailed as a matter of law in a third-party action against the vessel owner if the plaintiff's injuries resulted from the ship's unseaworthiness (a standard of care similar to strict hability) or the owner's neghigence. ${ }^{12}$ In Provenza v. American Export Lines, Inc., the first case to

6. For example, in Duty v. East Coast Tender Serv., 660 F.2d 933 (4th Cir. 1981) (en banc per curiam), cert denied, 102 S. CL. 1442 (1982), the Court of Appeals for the Fourth Circuit held that Scindia requires apphication of a maritime rather than a land-based negligence standard in section $905(\mathrm{~b})$ cases, and that under maritime law the violation of a statutory duty constitutes negligence per se. 660 F.2d at 947-48. In so holding, the Fourth Circuit extended the Scindia rationale beyond the bounds contemplated by the Supreme Court. See infra text accompanying notes 114-19.

7. See infra text accompanying notes 17-23.

8. See infra text accompanying notes 24-35.

9. See infra text accompanying notes 36-104.

10. See infra text accompanying notes $105-22$.

11. Act of Oct. 27, 1972, Pub. L. No. 92-576, 86 Stat. 1263 (amending 33 U.S.C. $88901-950$ (1976 \& Supp. IV 1980)).

12. See Seas Shipping Co. v. Sieracki, 328 U.S. 85 (1946). Because unseaworthiness approximates a standard of liability without fault on the part of the vessel owner, it is not surprising that most judgments against vessel owners were rendered on grounds of unseaworthiness. Very little case law prior to the enactment of the 1972 amendinents addresses the question of a breach of statutory duty in relation to negligence. Some of the older cases decided on unseaworthiness grounds contain dicta concerning the effect of a statutory violation in a negligence-based action. See, eg., Provenza v. American Export Limes, 324 F.2d 660, 665 -66 (4th Cir. 1963), cert. denied, 376 U.S. 952 (1964). However, only a few negligence-based cases based their holdings on statutory violations. These cases, though providing insight into the effect of a statutory violation in such actions, are of doubtful precedential value because the plaintiff invariably coupled his negligence-based claim with a claim based on unseaworthiness. Thus, in holding that a given statutory violation did not constitute negligence per se, courts did not preclude the phintifr's recovery. See, eg. . Copeland v. Oil Transp., Inc., 362 F. Supp. 11, 18-19, 20 (S.D. Ala. 1973) (violation of Coast Guard regulations designed to prevent fires does not constitute neghigence per se where plaintiff ijured as a result of asphyxiation; plaintiff allowed recovery on grounds of unseaworthiness). But 
consider the relationship between unseaworthiness and a statutory violation, 13 a plaintiff longshoreman was struck and injured by 1-beams allegedly lashed in violation of the Safety and Health Regulations for Longshoring. The Court of Appeals for the Fourth Circuit held that "in the area covered by the regulations their violation would render the ship unseaworthy, and if such unseaworthiness was the proximate cause of the plaintiff's injury, it would also render the defendant shipowner liable."14 The court emphasized that the regulation imposed on the shipowner ouly the standard of care required under traditional principles of maritime law: the absolute duty to provide a seaworthy vessel.15 The majority of preamendment "unseaworthiness" cases involving statutory violations followed the Provenza decision. ${ }^{16}$

\section{B. The Amendments.}

\section{The 1972 amendments to the LHWCA ${ }^{17}$ effected a compromise}

see Marshall v. Isthmian Lines, 334 F.2d 131 (5th Cir. 1964) (violation of Coast Guard regulations prohibiting the stowage of cotton bales with improper bindings does not constitute negligence per se; case remanded for new trial).

13. 324 F.2d 660, 662 (4th Cir. 1963), cert. denied, 376 U.S. 952 (1964).

14. 324 F.2d at 665 .

15. The regulation casts upon the shipowner no new duty nor does it relieve him of any pre-existing duty. Now, as before the regulation was promulgated, it is incumbent on him to supply a seaworthy ship. Now, as before, if the ship becomes unseaworthy through the aet of the stevedore or anyone else, and this condition is the proximate cause of an injury, the shipowner is liable. . . . All that the regulation does is to define how this well-established duty shall be discliarged. in particular circumstances . . . . It prescribes a standard of safety, not a new duty.

Id. at 665-66.

16. See Manning v. M/V "Sea Road", 417 F.2d 603, 611 (5th Cir. 1969); Boleski v. American Export Lines, 385 F.2d 69, 72 (4th Cir. 1967); Reid v. Quebec Paper Sales \& Transp. Co., 340 F.2d 34, 35 (2d Cir. 1965). A few cases, however, held that a violation of the Safety and Health Regulations for Longshoring, 29 C.F.R. $\$ 1918$ (1981), does not render a vessel unseaworthy per se. In Deffes v. Federal Barge Lines, 229 F. Supp. 719 (E.D. La. 1964), rev'd on other grounds, 361 F.2d 422 (5th Cir. 1966), the court stated that "[v]iolation of a safety regulation applicable to a stevedore does not render a vessel unseaworthy unless the violation crcates a dangerous condition aboard the vessel, which would constitute a defect in the vessel's hull, gear, stowage and appurte. nant appliances and equipment." 229 F. Supp. at 721 ; see also Albanese v. N. V. Nederl. Amerik Stoolnv. Maats., 346 F.2d 481, 483 (2d Cir.), rev'd per curiam, 382 U.S. 283 (1965); Tallmon v. Toko Kaium K.K. Kobe, 278 F. Supp. 452,457 (D. Or. 1967).

17. Act of Oct. 27, 1972, Pub. L. No. 92-576, 86 Stat. 1263 (amending 33 U.S.C. $\$ \$ 901-950$ (1970)). Section 905(b) provides:

In the event of injury to a person covered under this chapter caused by the negligence of a vessel, then such person, or anyone otherwise entitled to recover damages by reason thereof, may bring an action against such vessel as a third party in accordance with the provisions of section 933 of this title, and the employer shall not be lable to the vessel for such damages directly or indirectly and any agreements or warranties to the contrary shall be void. If such person was employed by the vessel to provide stevedoring services, no such action shall be permitted if the injury was caused by the negligence of persons engaged in providing stevedoring services to the vessel. If such person was einployed by the vessel to provide ship building or repair services, no such action shall be permitted if the injury was caused by the negligence of persons engaged in providing 
between the interests of longshoremen, stevedores, and shipowners. ${ }^{18}$ The amendments abolished both the longshoreman's judicially-created right to recover on a claim of unseaworthiness in third-party suits against vessel owners ${ }^{19}$ and the stevedore's obligation to indemnify the shipowner if the latter were lield liable in a third-party action. ${ }^{20}$ By eliminating unseaworthiness as a ground for recovery in third-party suits, Congress intended to place the injured longshoreman "in the same position he would be if he were injured in non-maritime employInent ashore . . . and not to endow him with any special maritime theory of liability or cause of action . . . ."21

The longshoreman plaintiff still may recover if the vessel owner's actions are the equivalent of land-based negligence. By retaining this statutory cause of action for negligence, Congress sought to promote safety in the longshoring industry. Congress did not intend to lessen the "responsibility [of the vessel owner] . . . where it knows or should have known about a dangerous condition." 22 The authors of the amendments contemplated that the only difference between section 905(b) neghigence actions and land-based neghigence actions would be the adjudication of section 905(b) actions under federal rather than state law, providing uniform application of the statutory remedy. ${ }^{23}$

\footnotetext{
ship building or repair services to the vessel. The liability of the vessel under this subsection shall not be based upon the warranty of seaworthiness or a breacl thereof at the time the injury occurred. The remedy provided in this subsection shall be exclusive of all other remedies against the vessel except remedies available under this chapter. 33 U.S.C. \& 905(b) (1976).

18. See generally S. ReP. No. $1125,92 d$ Cong., $2 d$ Sess. (1972); H.R. REP. No. 92-1441, 92d Cong., 2d Sess., reprinted in 1972 U.S. CODE CONG. \& AD. NEws 4698.

19. See Seas Shipping Co. v. Sieracki, 328 U.S. 85, 101-02 (1946). Although the Sierackt cause of action is no longer available under section 905 (b), it remains available to longshoremen in the Canal Zone under the Federal Employees' Compensation Act (FECA), 5 U.S.C. 888101 8193 (1976 \& Supp. IV 1981). See Aparicio v. Swan Lake, 643 F.2d 1109, 1114-18 (5th Cir. 1981); Pinto v. Vessel "Santa Isabel", 492 F. Supp. 689 (D.C.Z. 1980).

20. See 33 U.S.C. $8905(b)$ (1976). One purpose of the amendments was to reduce the number of LHWCA cases in the federal courts by increasing the barriers to recovery in third-party suits against vessel owners and simultaneously providing injured longshoremen with an adequate statutory scheme of compensation. Thus, the amendinents also increased the statutory rates of compensation. See 33 U.S.C. $\$ 8905,906,908$ (1976); H.R. REP. No. 1441, $92 d$ Cong., 2d Sess. $4-$ 7, reprinted in 1972 U.S. CODE CONG. \& AD. NEws 4698, 4702-03.
}

21. S. Rep. No. 1125, 92d Cong., $2 \mathrm{~d}$ Sess. 10 (1972).

22. Id Committee reports emphasize that the amendinents were not intended to reheve any person of his duties and obligations under the Occupational Safety and Health Act of 1970, Pub. L. No. 91-596, 84 Stat. 1590 (codified in scattered sections of 5, 15, 18, 29, 42 \& 49 U.S.C.).

23. Finally, the Committee does not intend that the negligence remedy authorized in the bill shall be applied differently in different ports depending on the law of the State in which the port may be located. The Committee intends that legal questions which may arise in actions brought under these provisions of the law shall be determined as a matter of Federal lap. In that connection, the Committee intends that the admiralty concept of comparative negligence, rather than the common law rule as to contributory negligence, shall apply in cases where the injured employee's own neghigence may have contributed 


\section{The Impact of Scindia.}

In Scindia Steam Navigation Co. v. De Los Santos, 24 a pallet fell from a defective winch and mjured a longshoreman. The winch was part of the ship's gear. ${ }^{25}$ At issue was the shipowner's duty of care under section 905(b) of the LHWCA. After reviewing the legislative history of the 1972 amendments to the Act, the Supreme Court rejected the land-based standard of care owed to invitees of landowners, as outlined in sections 343 and 343A of the Restatement (Second) of Torts. ${ }^{26}$ The Court adopted instead the standard applied below by the Court of Appeals for the Ninth Circuit:

A vessel is subject to liability for injuries to longshoremen working on or near the vessel caused by conditions on the vessel if, but only if, the shipowner (a) knows of, or by the exercise of reasonable care would discover, the condition, and should realize that it involves an unreasonable risk of harm to such longshoremen, and (b) the shipowner fails to exercise reasonable care under the circumstances to protect the longshoremen against the danger. ${ }^{27}$

The Court modified the Ninth Circuit's standard, ruling that "absent . . positive law or custom to the contrary," $2 \dot{8}$ the shipowner may rely on the stevedore to discover dangerous conditions that develop during cargo operations, and consequently has no continumg duty to

to causing the injury. Also, the Committee intends that the admiralty rule which precludes the defense of "assumption of risk" in an action by an injured employee shall also be applicable.

H.R. REP. No. 1441, 92́d Cong., 2d Sess. 8 (1972), reprinted in 1972 U.S. CODE Cong. \& AD. NEwS 4698, 4705.

24. 451 U.S. 156 (1981). See generally Note, The New Negligence Standard for Shipowners and Longshoremen-Scindia Steam Navigation Co. v. De Los Santos, 13 Loy. U. CH. L.J. 83 (1981).

25. 451 U.S. at 158-59.

26. Restatement (SECOND) OF TORTS $\$ \$ 343,343$ A (1965). Section 343 provides:

A possessor of land is subject to liability for physical harm caused to his invitees by a condition on the land, if, but only if, he

(a) knows or by the exercise of reasonable care would discover the condition, and shonld realize that it involves an unreasonable risk of harm to such invitees, and

(b) should expect that they will not discover or realize the danger, or will fail to protect themselves against it, and

(c) fails to exercise reasonable care to protect then against the danger.

Section 343A provides:

(1) A possessor of land is not liable to his invitees for physical harm caused to thein by any activity or condition on the land whose danger is known or obvious to them, unless the possessor should anticipate the harm despite such knowledge or obviousness.

(2) In determining whether the possessor should anticipate harm from a known or obvious danger, the fact that the invitee is entitled to make use of public land, or of the facilities of a public utility, is a factor of importance indicating that the harm should be anticipated.

27. De Los Santos v. Scindia Steam Navigation Co., 598 F.2d 480, 485 (9th Cir. 1979), affd, 451 U.S. 156 (1981).

28. 451 U.S. at 172. 
supervise or inspect the ship after delivering it to the stevedore. ${ }^{29}$ In - determining the extent of the shipowner's duty of care for the safety of longshoremen, a "necessary inquiry is whether the pertinent statutes, regulations, or customs place or assume a continuing duty on the vessel ....."30

The Court referred to "pertiment statutes, regulations, or customs"31 but failed to explain the meaning of the word "pertinent." The problems that may result from this oversight are exemphified by the recent decision of the Court of Appeals for the Fourtl Circuit in Duty v. East Coast Tender Service, Inc. ${ }^{32}$ In Duty, a section 905(b) aetion involving a violation of a Coast Guard licensing regulation by a shipowner, the Fourth Circuit expressly relied on Scindia. The court held that Scindia rejects the application of land-based neghigence standards in section 905(b) actions, and that under maritime law, violation of a statutory duty is negligence per se. ${ }^{33}$

29. Id. The Court noted that the standard of care announced by the Ninth Circuit in Scindio placed too high a duty of care on the vessel owner:

We are of the view that absent contract provision, positive law or custom to the contrary-none of which has been cited to us in this case-the shipowner has no general duty by way of supervision or inspection to exercise reasonable care to discover dangerous conditions that develop within the confines of the cargo operations that are assigned to the stevedore. The necessary consequence is that the shipowner is not liable to the longshoremen for injuries caused by dangers unknown to the owner and about which he had no duty to inform himself. This conclusion is plainly consistent with the congressional intent to foreclose the faultless liability of the shipowner based on a theory of unseaworthiness or nondelegable duty.

Id.

30. Id. at 176. The OSHA regulations involved in Scindia pertain to the use of a ship's gear by a stevedore. See 29 C.F.R. $\$ 81918.51-.53$ (1981). Section 1918.51(b) provides that "[a]ny component of cargo handling gcar . . . which is visibly unsafe shall not be used until nade safe." In addition, section 1918.53(a)(5), dealing with cargo winches, provides that "[alny defect or unalfunction of winches shall be reported immediately to the officer in charge of the vessel . . .." Even in the absence of another statute or regulation placing the obligation to repair a defective winch on the shipowner, a possible inference from the above provisions is that when a defective winch is discovered, it should not be repaired by the stevedore but reported to and repaired by the shipowner. 451 U.S. at 176-78.

31. Id at 176.

32. 660 F.2d 933 (4th Cir. 1981) (en banc) (per curiain), cert. denied, 102 S.Ct. 1442 (1982). The facts of this case were unusual. The plaintif, a carpenter foreman, was employed by the general contractor for a liquid natural gas (LNG) port facility located on the navigable waters of Chesapeake Bay. The defendant, East Coast Tender Service, provided access to and froun the job site. The plaintiff was at work on the job site when the weather deteriorated, and the defendant sent the vessel $M / V$ Chandeleur to transport the work crew to land. The commander of the $M / V$ Chandeleur was on vacation, and his replaceinent, though an experienced seaman, did not lave a Coast Guard operator's license as required under the Coast Guard regulations. See 46 C.F.R. 88 186.05-.10 (1981). Rough seas made the approach to the loading platform difficult. The vessel struck the platform, causing a ladder attached to the platform to break loose. The plaintif was thrown from the ladder and injured.

33. $660 \mathrm{~F} .2 \mathrm{~d}$ at $947-48$. 
By imterpreting Scindia to require the application of maritime standards in section 905(b) cases, the Duty court effectively circumvented the 1972 amendments to the LHWCA. In the amendments, Congress intended to limit shipowners' liability to cases im which the shipowner was actually negligent. ${ }^{34}$ By applying a inaritime standard to find that the violation of the regulation was negligence per se, the Fourth Circuit effectively returned to a standard of strict liability that the 1972 amendinents were intended to abolisl. ${ }^{35}$

\section{The Role of Statutory Duty in Section 905(b) Cases}

In enacting section 905(b), Congress intended the shipowner's liability to be predicated on its own negligence according to traditional principles of land-based tort law. Some decisions prior to Scindia recognized that violation of a statute or regulation may, in some circumstances, constitute negligence per se; however, those decisions are consistent with accepted principles of land-based tort law.

\section{A. Statutory Duty in the Land-Based Law of Torts.}

Under traditional land-based tort law, if a statute or regulation prescribes a particular standard of conduct, deviation from that standard may, in some circuinstances, be negligence per se. ${ }^{36}$ Section 286 of the Restatement (Second) of Torts suggests four factors to consider in determining whether a statute creates an absolute statutory duty to a particular plaintiff: (1) whether the statute was intended to protect a class of persons to which the plaintiff belongs; (2) whether the statute was intended to protect the particular interest invaded; (3) whether the statute was intended to protect that interest against the kind of harm that resulted; and (4) whether the statute was intended to protect that

\footnotetext{
We need say little more except to take note of Scindia Steam Navigation Co., Ltd. $v$. De Los Santos, . . . decided subsequent to the panel's decision of the instant case. . . . In deciding that a shipowner may be liable for negligence when he knows or sloould have known of a hidden danger but failed to warn the stevedore of it, the Court lent strong support to the view that a negligence action under $\$ 905(b)$ is more properly called "maritime" than "land-based."

.. . If there was any doubt before Scindia that a negligence action under $\S 905(b)$ miglit properly be called "maritime," it is erased.... Id.

34. See supra text accompanying notes 17-23.

35. See supra text accompanying notes 13-15.

36. W. Prosser, LAW OF TORTS 190 (4th ed. 1971). See generally Fricke, The Juridical Nature of the Action Upon the Statute, 76 LAw Q. REv. 240 (1960); James, Statutory Standards and Negligence in Accident Cases, 11 LA. L. REv. 95 (1951); Morris, The Role of Criminal Statutes in Negligence Actions, 49 COLUM. L. REV. 21 (1949); Morris, The Relation of Criminal Statutes to Tort Liability, 46 HARV. L. REV, 453 (1933) [hereinafter cited as Tort Liability]; Williams, The Effect of Penal Legislation in the Law of Tort, 23 MoD. L. REv. 232 (1960).
} 
interest against the particular hazard from which the harm resulted. ${ }^{37}$ If a statute meets all four criteria, the great majority of courts hold that an unexcused violation of the statute constitutes negligence per se. ${ }^{38}$ If all four criteria are not met, courts will either instruct the jury that the violation is evidence of neghigence or exclude evidence of the violation as irrelevant. ${ }^{39}$

In contrast, certain statutes impose an absolute statutory duty, the breach of which invariably constitutes negligence per se. Although courts frequently speak of the violation as "negligence per se,"40 such statutes properly fall under the rubric of strict liability. For example, the Federal Safety Appliance Act ${ }^{41}$ and the Boiler Inspection Act, ${ }^{42}$ which regulate the equipment of trains moving in interstate commerce; have been construed to impose an absolute duty in cases arising under the Federal Employers' Liability Act (FELA), ${ }^{43}$ and courts have construed United States Coast Guard regulations to impose an absolute duty in cases arising under the Jones Act. ${ }^{44}$ These statutes are limited exceptions to the general rule that in order for the violation of a statute to be negligence per se, it must satisfy the elements set fortl in the Restatement. ${ }^{45}$

37. RESTATEMENT (SECOND) OF TORTS § 286 (1965); see also id. \& 288.

38. See W. Prosser, supra note 36 , at $200-01$. A few jurisdictions hold that a violation is only evidence of negligence.

39. Prosser believes that the former is the better rule. "The arbitrary classification of all breaches of statute as negligence per se or no negligence at all leaves too little flexibility for the standard of reasonable care." Id. at 202. See also Tort Liability, supra note 36, at 453. Many courts have held that when a statute is construed not to cover the plaintiff, or the particular type of harm, its violation is not even evidence of negligence and can have no effect on liability at all. Thus, because the prevailing view outside of New Hampshire and Massachusetts is that licensing statutes are for revenue purposes only, most jurisdictions hold that the violation of a licensing statute cannot create hability for negligence. Some jurisdictions consider lack of a license completely immaterial. These jurisdictions include: Arkansas, California, Illinois, Maryland, Nevads, New Jersey, Vermont and West Virginia. See Duty v. East Coast Tender Serv., 660 F.2d 933, 943 n.l (4th Cir. 1981) (Winter, J., dissenting), cert. denied, 102 S. Ct. 1442 (1982).

40. W. Prosser, supra note 36, at 197. See Carter v. Allanta \& Si. A. B. Ry., 338 U.S. 430, .434 (1949).

41. 45 U.S.C. $\$ 81-16(1976)$.

42. 45 U.S.C. $\$ 822-34$ (1976).

43. 45 U.S.C. \&8 $51-60$ (1976); see Carter v. Atlanta \& St. A. B. Ry., 338 U.S. 430, 434 (1949); O'Donnell v. Elgin, J. \& E. Ry., 338 U.S. 384, 390 (1949); Urie v. Thompson, 337 U.S. 163, 188 (1949).

44. 46 U.S.C. 8688 (1976); see Kernan v. American Dredging Co., 355 U.S. 426, 438-39 (1958). For examples of other statutes that impose absolute statutory duties, see W. Prosser, supra note 36, at 197-98. See also infra note 52.

45. See supra note 37 and accompanying text. 


\section{B. Statutory Schemes Affecting Vessel Liability in Section 905(b) \\ Cases.}

Two distinct statutory scheines may impose hability on vessel owners in section 905(b) cases: Occupational Safety and Health Act (OSHA) regulations, ${ }^{46}$ and United States Coast Guard regulations. ${ }^{47}$ In the older LHWCA cases, particularly those decided prior to enactment of the 1972 amendments, courts referred in general terms to "statutory duty," failing to distinguish these two statutory schemes. However, the recent trend is to distinguish the two sets of regulations, their respective purposes, and the duties and rights they create. ${ }^{48}$

1. Statutory Duties Imposed by Coast Guard Regulations. By the Act of June 7, 1897,49 Congress authorized the United States Coast Guard to codify rules governing navigation on inland waters for the purpose of conforming to prevailing international rules for preventing collisions at sea.50 The regulations apply explicitly to "every pilot, engineer, mate, or master of any steam vessel . . . Provided, That nothing . . . shall reheve any vessel, owner, or corporation froni any liability incurred by reason of ... neglect or refusal [to comply with the regulations]." 51

Although Coast Guard regulations have been interpreted to impose a standard of strict liability in suits for personal injury or wrongful death brought under the Jones Act, ${ }^{52}$ courts have been reluctant to apply these regulations for the benefit of longshoremen in section 905(b) suits because longshoremen are not generally thought to be among the intended beneficiaries of the Act of 1897.53 The legislative history of

46. The regulations for longshoring and related employments are codified at 29 C.F.R. $\$ \S 1915-19$ (1981). These sections regulate ship repairing, ship building, shipbreaking, longshoring, and gear certification. See generally Miller, The Occupational Safety and Health Act of 1970 and the Law of Torts, 38 LAW \& CONTEMP. PrOBS. 612 (1974).

47. 33 C.F.R. $\$ \S 1-199,46$ C.F.R. $\$ \S 1-197$ (1981).

48. For a good discussion of the distinction between OSHA regulations and Coast Guard regulations, see Taylor v. Moore-McCormack Lines, 621 F.2d 88 (4th Cir. 1980). See also National Marine Serv. v. Gulf Oil Co., 433 F. Supp. 913, 920 (E.D. La. 1977).

49. 30 Stat. 102 (codified in scattered sections of 33 U.S.C.).

50. H.R. Doc. No. 42, 55th Cong., Ist Sess. 1 (1897).

51. 33 U.S.C. $\& 158$ (1976) (emphasis added).

52. 46 U.S.C. $\$ 688$ (1976). The Jones Act entitles a seaman or his representative to recover for personal injury or death caused by his employer's negligence. In actions brought inder the Act "all statutes of the United States inodifying or extending the common-law right or remedy in cases of personal injury to railroad employees shall apply . . . ." Id. The Jones Act thus incorporates the provisions of the FELA, 45 U.S.C. $\$ \$$ 51-60 (1976). See generally G. Gllmore \& C. BlaCk, supra note 3 , at 325-83.

53. See Marshall v. Isthmian Lines, 334 F.2d 131 (5th Cir. 1964). 
the Act supports this conclusion, as do the regulations themselves. ${ }^{54}$ Moreover, the Occupational Safety and Health Review Commission has determined that the regulations do not apply to longshoremen. ${ }^{55}$ Nevertheless, a few courts have held that Coast Guard regulations impose a duty on the vessel owner for the benefit and protection of longshoremen.

Of these cases, the best known and most often cited is Marshall $v$. Isthmian Lines. ${ }^{56}$ The plaintiff im Marshall was imjured when an allegedly defective binding on a bale of cotton broke, causing the bale to fall on him. The plaimtiff argued that the shipowner's violation of Coast Guard regulations im accepting and stowing defectively bound cotton constituted negligence per se. ${ }^{57}$ The Court of Appeals for the Fifth Circuit held that the violation should be presented to the jury as evidence of negligence, but that it did not constitute negligence per se. ${ }^{58}$ In rejecting the negligence per se approach, the court considered traditional land-based rules of tort law concerning statutory duty as set forth in section 286 of the Restatement:

The law is well established that violation of a statute which is intended to protect the class of persons to which a plaintiff belongs against the risk of the type of harm which has in fact occurred is negligence in itself. . . . Inherent in this statement of the legal primciple are three questions which must be resolved before liability could be imposed in this case on a negligence per se theory. What proof makes out a violation of the regulations? Were the regulations designed to protect longshoremen? Were they intended to protect against the risk of the kind of harm that occurred here . . . s9

.54. See H.R. Doc. No. 42, 55th Cong., 1st Sess. 1 (1897). The Act was not a safety statute; it was not intended to protect any class of persons from the risk of any particular harm.

55. California Stevedore \& Ballast Co., 1 O.S.H. Cas. (BNA) 1757, 1758 (1974). The Commission wrote that:

With the arguable exception of one provision relating to the carriage of dangerous substances the provisions of the Shipping Code as they relate to occupational safety appear to apply to seamen as a class to the exclusion of longshoremen as a class. Indeed, were this not the case there would have been no necessity to amend the Longshoremen's and Harbor Worker's Compensation Act so as to authorize the Secretary of Labor to promulgate and enforce safety standards relating to longshoring operations.

Id. (footnotes omitted) (rebutting contention by defendant stevedore that the Coast Guard has statutory authority to promulgate regulations applicable to the working conditions of longshoremen); accord T. Smith \& Son, 2 O.S.H. Cas. (BNA) 1177 (1974); see also Marshall v. Isthmian Limes, 334 F.2d 131 (5th Cir. 1964). Conversely, OSHA regulations have been held inapplicable to the working conditions of seamen on vessels operating on the high seas. See, eg., Clary v. Ocean Drilling \& Exploration Co., 609 F.2d 1120 (5th Cir. 1980).

56. 334 F.2d 131 (5th Cir. 1964). Although this case arose prior to the enactment of the 1972 amendments, the plaintiff did not raise a claim of unseaworthiness; the case therefore addressed solely the plaintif's claim of negligence.

57. Id. at 133-34.

58. Id. at 136 .

59. Id. at 134 . 
The court held that the shipowner had violated the regulation, and that the regulation was designed to protect "all persons who work on or come into relation to the vessel," 60 including longshoremen. However, the court found that the regulation in question was intended to guard agamst the risk of "fire, explosion, and related harms," 61 and not the kind of harm that befell the plaintiff. The violation of the regulation therefore was not negligence per se. The court carefully limited its holding to the facts of the case and the specific regulation involved. It noted that violations of some Coast Guard regulations, particularly those related to the transportation of dangerous substances, "inay well give rise to per se consequences." 62 The traditional criteria announced in Marshall have been applied by courts in other LHWCA cases involving Coast Guard violations, ${ }^{63}$ and in a few cases involving OSHA violations. ${ }^{64}$

\section{Statutory Duties Imposed by OSHA Regulations. Congress} amended section 1 of the LHWCA in $1958^{65}$ to permit the promulgation of regulations applicable to all employers under the Act to promote safety and reduce the high rate of injury in the longshoring industry. ${ }^{66}$ The result was a series of maritime regulations known as

60. Id. at 135.

61. Id. (footnote omitted).

62. Id at 136. Coast Guard regulations pertaining to the carriage of dangerous substances are codified at 46 C.F.R. $\$ \$ 146-54 a$ (1981).

One example of the kind of exceptional case envisioned by the court in Marshall is In re Allied Towing Corp., 416 F. Supp. 1207 (E.D. Va. 1976), aff' in part and vacated in part on other grounds sub nom. Allied Towing Corp. v. Tatem, 580 F.2d 702 (4th Cir. 1978). Allied Towing involved a shipowner's petition for limitation of liability for the deaths of three ship repairmen. Evidence disclosed that immediately before a barge exploded it was carrying a grade of fuel with a flash point range below that for which it was certified under Coast Guard regulations. The court found the vessel owner negligent for failing to ensure compliance with the regulation. Although the court in Allied Towing did not apply the Marshall criteria, a careful reading of the facts indicates that these criteria were met: (1) there was an undisputed violation of the regulation involved; (2) the regulation was intended to protect ship repairmen; and (3) the regulation was intended to protect against the risk of the kind of harm that occurred-in this case, fire and explosion.

63. See Copeland v. Oil Transp., Inc., 362 F. Supp. 11 (S.D. Ala. 1973). In Copeland a longshoreman died as a result of inhaling poisonous gas fumes while removing a manhole cover from the cofferdam of a vessel in dry dock. The plaintiff alleged that the vessel owner was negligent in failing to test for dangerous gases as required by Coast Guard regulations. The court found that the regulation was intended to prevent fire or explosion rather than asplyxiation. Thus, the regulation did not ineet the Marshall criteria, and the violation was merely evidence of negligence.

64. See infra notes 80-89 and accompanying text.

65. Pub. L. No. 85-742, 72 Stat. 835 (amending 33 U.S.C. $\$ 941$ (1952)).

66. H.R. REP. No. 2287, 85th Cong., 2d Sess. 1-3 (1958), reprinted in 1958 U.S. CODE CONG. \& AD. NEWS 3843,3844 . In 1958 the injury rate in the longshoring industry was approximately seven times higher than the injury rate in manufacturing activities. 
" 'the Bible' for the stevedore industry,"67 which was incorporated into the body of OSHA regulations pursuant to sections 6 and $8(\mathrm{~g})$ of the OSHA.68

Despite various changes in the regulations, the introductory sections have remained unaltered smce their promulgation in 1960 and bear directly on the applicability of OSHA standards to shipowners. Section 1918.2 states:

(a) The responsibility for compliance with the regulations of this part is placed upon 'employers' as defined in § 1918.3(c).

(b) It is not the intent of the regulations of this part to place additional responsibilities or duties on owners, operators, agents, or masters of vessels unless such persons are acting as employers, nor is it the intent of these regulations to relieve such owners, operators, agents, or masters of vessels from responsibilities or duties now placed upon them by law, regulation or custom. ${ }^{69}$

Although the courts in Provenza v. American Export Lines, Inc. ${ }^{70}$ and other pre-ainendment LHWCA cases $^{71}$ had stated in dicta that a breach of the OSHA regulations for longshoring by the stevedore or shipowner could constitute vessel neghigence as well as unseaworthiness, the post-amendment federal appellate decisions have held almost without exception that a shipowner cannot be held liable for such a breach by the stevedore. ${ }^{72}$ The Court of Appeals for the Fifth Circuit in Gay v. Ocean Transport \& Trading, Ltd. ${ }^{73}$ flatly rejected the plaintiff's

67. Nymphe S.S. Co. v. Atlantic \& Gulf Grain Stevedoring Assocs., 383 F.2d 876, 877 (1st Cir. 1967).

68. See 29 U.S.C. 88655,657 (1976).

69. 29 C.F.R. 81918.2 (1981) (emphasis added). This language indicates that the terms "employer" and "vessel owner" are not synonymous. Section 1918.3(c) further differentiates between "employer" and "vessel owner" by defining an employer as one "whose employees are employed, in whole or in part, in longshoring operations or related employinents, as defined herein within the Federal maritime jurisdiction on the navigable waters of the United States." 29 C.F.R. 8 1918.3(c) (1981). "The term 'related einployinents' means any employments performed as an incident to or in conjunction with longshoring operations including, but not restricted to, securing cargo, rigging, and employmeat as a porter, checker, or watchman." 29 C.F.R. 8 1918.3(j) (1981).

70. 324 F.2d 660 (4th Cir. 1963), cert. denied, 376 U.S. 952 (1964).

71. See, e.g., Manning v. M/V "Sea Road", 417 F.2d 603 (5th Cir. 1969); Boleski v. American Export Lines, 385 F.2d 69 (4th Cir. 1967); Price v. S.S. Yaracuy, 378 F.2d 156 (5th Cir. 1967); Reid v. Quebec Paper Sales \& Transp. Co., 340 F.2d 34 (2d Cir. 1965).

72. Courts have also held that the stevedore cannot avoid the statutory obligations imposed by OSHA regulations by contracting with the vessel to have the ship's crew perform these duties. See, eg., Doca v. Marina Mercante Nicaraquense S.A., 474 F. Supp. 751 (S.D.N.Y. 1979), aff' in parn and vocated in part, 634 F.2d 30 (1980), cert. denied, 451 U.S. 971 (1981); Croshaw v. Koninklijke Nedlloyd, B.V. Rijswijk, 398 F. Supp. 1224 (D. Or. 1975).

73. 546 F.2d 1233 (5th Cir. 1977). In Gay the stevedore had violated 29 C.F.R. 8 1918.93(a)(1)(i) (1981), which requires the employer to measure carbon monoxide levels in closed comparments within $\mathbf{3 0}$ minutes after placement of a forklif in the compartment. 
claim that an OSHA regulation could provide the standard of care for a negligence action against the vessel: "Gay's arguınent is, in effect, that the vessel has a non-delegable duty to provide a longshoreinan with a safe place to work. But this is exactly the type of liability without fault concept from which Congress sought to free vessels by the passage of the 1972 Amendments."74

The Court of Appeals for the Second Circuit has recently adopted and extended this rationale to permit the use of OSHA regulations as evidence to establish whether the shipowner could reasonably anticipate that the stevedore would take "special precautions" to ensure the safety of the longshoremen. In Evans v. Transportation Maritima Mexicana, S.S. "Campeche"7s the court stated that "the stevedore's warranty of workmanlike performance ... is an implied covenant of every shipowner/stevedore contract."76 Thus, the jury should be instructed on the contents of applicable OSHA regulations in determining whether the shipowner reasonably relied on the stevedore's warranty of workmanlike performance. ${ }^{77}$ The Court of Appeals for the Ninth Circuit reached a similar conclusion in Davis v. Partenreederei M.S. Normannia ${ }^{78}$ There the court approved a jury instruction that placed the sole responsibility for compliance with OSHA regulations

74. 546 F.2d at 1239. Accord Albergo v. Hellenic Lines, Inc., 658 F.2d 66 (2d Cir. 1981) (decided after Scindia); Chavis v. Finnlines Ltd., O/Y, 576 F.2d 1072 (4th Cir. 1978); Brown v. Mitsubishi Shintaku Ginko, 550 F.2d 331 (5th Cir. 1977); Losado v. Cardigan Shipping Co., 1982 A.M.C. 1208 (S.D.N.Y. 1981) (decided after Scindia); Garofalo v. Malaysia Overseas Export Lines, 470 F. Supp. 160 (S.D.N.Y. 1979); Gallardo v. Westfal-Larsen \& Co. A/S, 435 F. Supp. 484 (N.D. Cal. 1977); Croshaw v. Koninklijke Nedlloyd, B.V. Rijswijk, 398 F. Supp. 1224 (D. Or. 1975); Anuszewski v. Dynamic Mariners Corp. Panama, 391 F. Supp. 1143 (D. Md. 1975), affd, 540 F.2d 757 (4th Cir. 1976), cert. denied, 429 U.S. 1098 (1977); Hite v. Maritime Overseas Corp., 375 F. Supp. 233 (E.D. Tex. 1974).

75. 639 F.2d 848 (2d Cir. 1981).

76. Id. at 859. See Ryan Stevedoring Co. v. Pan-Atlantic S.S. Corp., 350 U.S. 124 (1956). The Ryan Court determined that by contractually undertaking to stow cargo in a reasonably safe manner the stevedore warrants its services to the shipowner. Prior to the enactment of the 1972 amendments the shipowner could bring a claim for indemnification for a breach of this warranty.

77. The Evans court explained:

It is totally unrealistic to assume that a jury can meaningfully assess shipowner anticipation in the stevedoring context without being inforned that the stevedore bears the priinary responsibility to correct dangerous conditions and that the shipowner will often rely on the stevedore to do so . . . And in order that the jury have a concrete idea of what that primary responsibility consists of, the trial court should instruct the jury as to the contents of the relevant Safety and Health Regulations for Longshoring ....

639 F.2d at 860. But cf. Gallardo v. Westfal-Larsen \& Co. A/S, 435 F. Supp. 484, 501 (N.D. Cal. 1977), in which the court stated:

[M]aritime regulations adopted under OSHA may be admissible in nonjury trials to exemplify the types of safety responsibilities which one kind of employer in the shipping industry (i.e, a stevedore) owes to its employees. ... In the context of a court trial, admission of the OSHA regulations does not prejudice the arguments of either party.

78. 657 F.2d 1048 (9th Cir. 1981). 
on the plaintiff's employer, the stevedore, and thus used the regulations as evidence of limitations on the shipowner's duty of care to the longshoremen. ${ }^{79}$

Despite the vast majority of cases holding that the burden of complying with OSHA regulations rests solely on the stevedore, in a few isolated cases courts have held the vessel owner liable for a breach of these regulations. These cases can be divided into two categories: cases in which the vessel owner has retained control over the operative details of the longshoring operations, and cases involving a pre-existing condition of the vessel in breach of regulations.

(a). Cases involving vessel control over operative details of longshoring operations. In two recent cases that involved OSHA violations by stevedores, Bachtel v. Mammoth Bulk Carriers ${ }^{80}$ and Lawson v. United States, ${ }^{81}$ the Ninth Circuit Court of Appeals held that OSHA regulations may impose a standard of care on the vessel owner. Because these cases were decided in the wake of that court's decision in De Los Santos v. Scindia Steam Navigation Co. ${ }^{82}$ they seened to signify a shift in the Ninth Circuit's approach to defining the standard of care owed by vessel owners to longshoreinen. However, the court's inore recent decision in Davis v. Partenreederei M.S. Normannia ${ }^{83}$ indicates that the court agrees with the Second, Third, and Fifth Circuit Courts'84 interpretation of "reasonable care under the circumstances" standard, as modified by the Suprene Court in Scindia. ${ }^{85}$ Yet the Da-

79. Davis involved the positioning of a gangway in violation of OSHA regulations. A jury returned a verdict in the plaintiff's favor, finding the shipowner $20 \%$ negligent, the stevedore $40 \%$ negligent, and the plaintiff $40 \%$ negligent. The court of appeals affirmed a denial of the defendant shipowner's motion for judgment n.o.v., holding that there was sufficient evidence to allow the jury to conclude that the vessel was $20 \%$ negligent. The court noted, however, that it was proper for the trial court to have instructed the jury that the sole responsibility for compliance with OSHA regulations in that case rested with the plaintiff's employer, and that "[t]he existence of the regulation and its reference to the stevedore's duty clearly assisted the shipowner's case." Id. at 1053.

80. 605 F.2d 438 (9th Cir. 1979), vacated, 451 U.S. 978 (1981) (remanded for further proceedings consistent with Scindia).

81. 605 F.2d 448 (9th Cir. 1979).

82. 598 F.2d 480 (9th Cir. 1979), affd, 451 U.S. 156 (1981).

83. 657 F.2d 1048 (9th Cir. 1981).

84. This was also the position of the Fourth Circuit prior to its decision in Duty. See supra notes 73-77 and accompanying.text.

85. In Bachtel, a case decided prior to the Supreme Court's decision in Scindia, the Ninth Circuit upheld a trial court decision to submit relevant OSHA regulations to the jury as evidence of vessel negligence. 605 F.2d at 446. In Davis, a post-Scindia decision, the court approved a jury instruction that the sole responsibility for compliance with OSHA regulations rests with the stevedore. 657 F.2d at 1053. 
vis court did not overrule Bachtel or Lawson. These decisions must therefore be explained by the peculiar facts of each case.

The vessel owner in Bachtel had directed the stevedore in loading logs on the vessel, using a "method chosen by [the crewmen] and dictated by the vessel's design and equipment." 86 The deck load of logs, as constructed under the direction of the vessel owner, was nearly twenty feet high, and the vessel owner knew that the stevedore could not rig a safety net as required by OSHA regulations. ${ }^{87}$ The court of apppeals ruled that the regulations applied to the vessel owner as well as to the stevedore, and upheld a jury instruction that the vessel owner's failure to comply with these regulations was evidence of negligence..$^{88}$

The vessel owner in Lawson reserved in its contract with a ship repair contractor the power to inspect and control the operative details of the work to be performed. The vessel owner also reserved the riglit to forbid dangerous practices that would create an unreasonable risk of harm to its mvitees. The contractor violated OSHA regulations that required it to provide planked walkways, work platforms, safety ropes, guardrails, and safety passages on construction sites. The court relied on its decision in Bachtel, holding the shipowner liable for the contractor's noncounpliance with the regulations. ${ }^{89}$

The results of Bachtel and Lawson are consistent with other section 905(b) cases holding the shipowner liable when it had actual knowledge of an unreasonably dangerous condition or risk of harm to longshoremen..$^{90}$ Because the defendants in Bachtel and Lawson re-

\section{605 F.2d at 443 .}

87. Id.

88. Stressing that the regulations were not intended to relieve owners, operators, or masters from responsibilities and duties then placed upon thein by law or custom, the court concluded that designing a 20-30 foot deck load of logs without safety nets would have been evidence of negligence under the law as it existed prior to 1972. Id. at 445. The court lield that OSHA regulations are binding on the shipowner "where lee knew or should have known" of a violation of a regulation by the stevedore. Id. The court applied the analysis used by the Court of Appeals for the Finth Circuit in Marshall v. Isthmian Limes, 334 F.2d 131 (5th Cir. 1964), in determining that the violation did not constitute negligence per se. See supra text accompanying note 59.

89. 605 F.2d at 453; $c$. Ryder v. United States, 513 F. Supp. 551 (D. Mass. 1981) (where shipowner retained control over operative details of ship repair work and contractor violated OSHA regulations requiring it to tag and isolate all steam valves prior to working on piping system, shipowner held concurrently negligent under long-standing custom and practice in the shipping industry that imposes upon the vessel the duty of isolating, locking or tagging steam valves).

90. See, e.g., Lubrano v. Royal Neth. S.S. Co., 572 F.2d 364 (2d Cir. 1978). The court stated that:

[i]f the evidence shows only that a ship's officer told the longshoreman to stop working until the dunnage arrived, thereby fulfilling the ship's duty to the longshoreman, there would be no case for the jury. But if there is again evidence that a ship's officer, after 
tained control ${ }^{91}$ over the operative details of the longshoring operations, they could be charged with actual or constructive knowledge of an unreasonably dangerous condition or risk of harm. Yet the Ninth Circuit did not base its holding on a notice theory, but rather on the 'statutory duty that was imposed on the shipowner by the OSHA regulations.

Although the rationale in Bachtel and Lawson appears to be contrary to existing case law involving OSHA violations by stevedores, the apparent contradiction may be resolved by examining the role of the shipowner in these cases vis-d-vis the individual longshoremen. By retaining control over the operative details of the longshoring operations, the shipowners in Bachtel and Lawson became the de facto employers of the longshoremen. In section 905(b) cases involving the direct employment of longshoreinen by shipowners, ${ }^{92}$ the shipowners have been held to a higher duty of care for the safety of the longshoreinen. ${ }^{93}$

being notified of the open and obvious danger of insufficient dunnage for a slippery cargo, had the inen keep working or joined in the stevedore's decision to do so, then there would be a jury question.

Id at 367 (footnote omitted); see also Lieggi v. Maritime Co. of the Phil., "M/V Philippine Rizal", 667 F.2d 324, 328-29 (2d Cir. 1981) (ship's mate notified of grease spill on topping lift); Uavis v. Partenreederei M.S. Normannia, 657 F.2d 1048, 1052 (9th Cir. 1981) (evidence that ship's officer "saw and appreciated" the danger); Lopez v. A/S D/S Svendborg, 581 F.2d 319, 321 (2d Cir. 1978) (shipowner knew of dangerous condition and stood silently by while stevedore told longshoremen to "keep working" and "be careful").

91. The court in Blackburn v. Prudential Lines, 454 F. Supp. 1302 (E.D. Pa. 1978), explained the concept of "control" as used in the context of $\$ 905(\mathrm{~b})$ actions:

[T] he "passing of control" to the stevedore alluded to in [\$ 905(b)] cases is not conclusive of the shifting of the responsibility for control, despite the seinantic similarity. Rather, this phrase refers in the shipowner-stevedore context to non-existence of a duty upon the former to supervise the latter, the shipowner's ability to delegate its duties and the unavailability of respondeat superior to hold the shipowner liable for the stevedore's employees.

Id. at 1309 n.6. See also Landsein v. Isuzu Motors, 534 F. Supp. 448 (D. Or. 1982), in which the court wrote:

- Plaintiff argues that the shipowner had a duty in regard to the lighting because the lights were equipment that remained in the active control of the shipowner during cargo operations. ... It may be true that the lights on the ship remained in the control of the shipowner. But the lighting in that area did not remain in the control of the shipowner.

Id. at 451 (emphasis in original).

92. Longshoreinen are usually einployed by independent stevedoring contractors. Occasionally, however, longshoreinen are hired directly by shipowners. Although the LHWCA as originally enacted provided only for a third-party cause of action against vessel owners, in Reed v. The Yaka, 373 U.S. 410 (1963), the Supreine Court held that a longshoreman employed directly by a shipowner could maintain an action against the vessel under the LHWCA. Congress codified the holding of Reed in section 905(b) of the LHWCA. See supra note 17 for text of $8905(\mathrm{~b})$. See also Napoli v. [Transpacific Carriers, Etc.] Hellenic Lines, 536 F.2d 505, 506-07 (2d Cir. 1976); Griffith v. Wheeling Pittsburgh Steel Corp., 521 F.2d 31, 40-44 (3d Cir. 1975), cert. denied, 423 U.S. 1054 (1976).

93. See, eg., Fanetti v. Hellenic Lines, 678 F.2d 424, 428 (2d Cir. 1982); Robertson v. Jeflboat, Inc., 651 F.2d 434, 436 (6th Cir. 1981), pettion for cert. flled, 51 U.S.L.W. 3060 (U.S. Nov. 
These cases emphasize that when a shipowner acts as its own stevedore instead of engaging the services of an independent contractor, it assunes sole responsibility for the safety and welfare of its longshoremen employees. ${ }^{94}$ The shipowner qua stevedore is presuined to have actual knowledge of any unreasonably dangerous condition or risk of harm to longshoremen, ${ }^{95}$ and it cannot claim to have rehed on the stevedore's warranty of workmanlike performance. ${ }^{96}$ Moreover, when the shipowner acts as its own stevedore, it has a statutory duty to comply with OSHA regulations because these regulations expressly apply to "employers" of longshoremen.97 Thus the shipowner qua stevedore may be held liable for the violation of a regulation that does not apply to the shipowner qua shipowner.98

(b). Cases involving a pre-existing condition of the vessel in breach of regulations. At least two courts have held a shipowner liable for negligence because of a pre-existing condition of the vessel that vio-. lated an OSHA longshoring regulation. Thus in Julien v. Lykes Brothers Steamship Co. 99 the shipowner was held liable for failure to provide safety railings around lightening holes in the saddle of a barge as required by OSHA regulations. The court distinguished an earlier case $^{100}$ holding that the safety and health regulations apply only to the

17, 1981) (No. 81-935); Napoli v. [Transpacific Carriers, Etc.] Hellenic Lines, 536 F.2d 505, 508 (2d Cir. 1976). See also Canizzo v. Farrell Lines, 579 F.2d 682, 689-90 (2d Cir. 1978) (Friendly, J., dissenting), cert. denied, 439 U.S. 929 (1978).

94. "Where . . . there is no independent contractor, it is part of the ship's duty to exercise reasonable care to inspect its own workers' workplace, to remove grease spills, etc. In such a case there is no 'independent contractor' with primary responsibility upon whom the ship may properly rely." Canizzo v. Farrell Lines, 579 F.2d 682, 689 (2d Cir. 1978) (Friendly, J., dissenting), cert. denied, 439 U.S. 929 (1978), quoted in Fanetti v. Hellenic Lines, 678 F.2d 424, 428 (2d Cir. 1982) (eniphasis in original).

95. See, eg., Robertson v. Jeffboat, Inc., 651 F.2d 434 (6th Cir. 1981), petition for cert. filed, 51 U.S.L.W. (U.S. Nov. 17, 1981) (No. 81-935). "Because Jefiboat is both owner and employer, any knowledge chargeable to it as employer must also be attributed to it as owner." 651 F.2d at 436 (emphasis in original).

96. See, e.g., Napoli v. [Transpacific Carriers, Etc.] Hellenic Lines, 536 F.2d 505, 508 (2d Cir. 1976) ("[A] charge which relieves a shipowner of liability for a dangerous condition which was 'known to the stevedore or to any of its employees' is clearly inappropriate where the shipowner, itself, is the stevedore.").

97. See supra text accompanying note 69.

98. Although no case involving the direct enployinent of longshoremen has held that OSHA regulations impose a statutory duty on shipowners, this is a logical extension of the rationale of the cases discussed above.

99. 1977 A.M.C. 241 (E.D. La. 1976).

100. See Hite v. Maritime Overseas Corp., 375 F. Supp. 233 (E.D. Tex. 1974). Hite was the first case to address the issue of the statutory duty imposed on shipowners by OSHA regulations after the enactment of the 1972 amendments. The Hite court held that the plaintiff had no negligence claim against the shipowner based on 2 violation of OSHA regulations by the stevedore. 
plaintiff's employer:

As far as the violation of OSHA regulations serving as a basis for a negligence action, Hite is quite correct. However, the alleged violation in the instant case was caused directly by the shipowner who participated in the design of the saddle. . . .

... [W] [Wile violations of OSHA regulations may not constitute the basis for a negligence action, they can be indicia of neghigent activity . . . . 101

An older and more famous case imvolving a similar violation of OSHA regulations by a shipowner is Arthur v. Flota Mercante Gran Centro Americana, S.A. ${ }^{102}$ The vessel in Arthur was in violation of OSHA regulations requiring handrails on certain kinds of ladders. The Arthur court applied the logic of Marshall v. Isthmian Lines ${ }^{103}$ to hold the shipowner negligent per se. The court emphasized that it was the duty of the shipowner to provide safe access to the ship. ${ }^{104}$

Althougl the rationale of the Arthur court differs from that enployed in Julien, both cases hold that OSHA regulations impose a statutory duty on shipowners. However, the holdings of Arthur and Julien must be narrowly interpreted. Both cases involve a pre-existing condition of the vessel over which the vessel owner alone had control, an OSHA violation "caused directly by the shipowner" that the stevedore could not reasonably be expected to remedy. These cases thus represent a well-defined, narrow exception to the general rule that OSHA regulations do not impose liability on vessel owners.

\section{IMPLICATIONS OF Scindia}

\section{A. Reconciling Scindia with Existing Section 905(b) Case Law.}

The Supreme Court remanded Scindia Steam Navigation Co. v. De

101. 1977 A.M.C. at $245-46$.

102. $487 \mathrm{~F} .2 \mathrm{~d} 561$ (5th $\mathrm{Cir}$. 1973). Although Arthur involved a cause of action arising before the enactment of the 1972 amendments, the case was decided solely on negligence grounds. The trial court found it unnecessary to consider the charge of unseaworthiness since the defendant had already been found to be neghigent. $/ d$ at 562 n.l.

103. 334 F.2d 131 (5th Cir. 1964). See supra text accompanying note 59.

104. The responsibility for providing safe access was solely that of the shipowner, not the responsibility of the employees of National Cargo. There is no evidence showing that National Cargo's employees contributed in any way to the creation of the dangerous condition. The shipowner did not fulfill its duty to furnish safe access, and it is responsible for its own negligence.

487 F.2d at 564 . Some courts believe Arthur was overruled by the Finh Circuit's decision in Gay v. Ocean Transp. \& Trading, Ltd., 546 F.2d 1233 (5th Cir. 1977). See, e.g., Gallardo v. WestfalLarsen \& Co. A/S, 435 F. Supp. 484, 498-99 n.16 (N.D. Cal. 1977). However, Arthur is distinguishable from Gay on its facts. Arthur involved the violation by the shipowner of OSHA regulations requiring handrails on certain kinds of ladders, whereas Gay involved the failure of the stevedore to ascertain carbon monoxide levels during cargo operations. See supra text accompanying notes 73-74. 
Los Santos ${ }^{105}$ and instructed the trial court to analyze pertinent OSHA and Coast Guard regulations to determine the relative liabilities of the shipowner and stevedore. The Court.concluded that because OSHA regulations require the stevedore to report any defective equipment to the ship's mate and to refrain from using or tampering with the equipment until repaired, a jury might reasonably find that if the shipowner knew of the defect, he had a duty to intervene and stop the loading operation until the defect was repaired. ${ }^{106}$ The Court likewise intimated that Coast Guard gear certification regulations might impose a continuing duty on the shipowner to maintain and repair its gear and to inspect the ship's equipment during cargo operations. ${ }^{107} \mathrm{By}$ implying that OSHA and Coast Guard regulations may impose a duty of care on the shipowner, Scindia appears to conflict with the prevailing view of statutory duty in section 905(b) cases-that sole responsibility for coinpliance with OSHA regulations rests with the stevedore ${ }^{108}$ and that violations of Coast Guard regulations are not negligence per se unless the regulation in question is intended to prevent the risk of a particular harin to a class of individuals which includes longshoremen. ${ }^{109}$

A comparison of Scindia and cases that exemplify the prevailing view demonstrates, however, that no conflict exists. The court in Marshall stated that a vessel owner may be liable for failing to comply with a Coast Guard regulation if the regulation meets the criteria listed by the Restatement. ${ }^{10}$ The regulation discussed in Scindia required the periodic inspection and certification of the ship's gear. ${ }^{11}$ Certainly such a regulation could be found to be for the protection of longshoremen using the gear in question. The regulation also could be inter-

105. 451 U.S. 156 (1981).

106. 451 U.S. at 176-78.

107. Id. at $177 \mathrm{n} .25$. The Court cited with approval the Second Circuit's decision in Irizarry v. Compania Maritima Navegacion Netumar, S.A., 1981 A.M.C. 2424 (2d Cir. 1980), cert. denied, 451 U.S. 969 (1981), involving a vessel violation of the Joint Maritime Safety Code issued by the New York Shipping Association, the International Longshoremen's Association, and the Port of New York Joint Safety Committee. The Second Circuit ruled that the safety code, which expressly applied to " "[t]he owner, inaster and officers of the vessel," placed an affirmative statutory duty on the vessel and its crew to "inaintain in safe condition for use all ship's gear, equipment, tools and work spaces . . . used in stevedoring operations." 1981 A.M.C. at 2425-26 (citing the Joint Maritime Safety Code). See supra text accompanying note 37.

108. Gay v. Ocean Transp. \& Trading, Ltd., 546 F.2d 1233 (5th Cir. 1977). See supra text accoinpanying notes 73-74.

109. Marshall v. Isthmian Lines, 334 F.2d 131 (5th Cir. 1964). See supra text accompanying notes 56-62.

110. See supra text accompanying notes 61-62.

111. These Coast Guard regulations were not applicable in Scindia because the vessel M/S Jalaratna was an Indian ship and therefore not covered by the regulations. 
preted as protecting against the risk of harm or injury resulting from the gear's malfunction. Thus, the result reached in Scindia satisfies the land-based negligence per se test outlined in Marshall. ${ }^{112}$

Furthermore, in limited circumstances OSHA regulations may be applied against the vessel in a section 905(b) action. The vessel owners im Arthur and Julien were held liable for pre-existing dangerous conditions on the vessel that violated OSHA regulations. ${ }^{113}$ Scindia similarly involved a defective part of the ship's gear, an electrical winch. The Supreme Court's determination that OSHA regulations imposed on the shipowner a duty to repair the wincl is consistent witl the rulings in Julien and Arthur that the shipowner liad a duty under OSHA regulations to turn the vessel over to the stevedore in a safe condition. In all three cases, the dangerous conditions were under the control of the vessel owners. Thus the owner had a duty to remedy the dangerous condition.

Despite this consistency with previous judicial decisions, the Fourth Circuit in Duty v. East Coast Tender Service, Inc. ${ }^{114}$ interpreted Scindia to require application of maritime law to section 905(b) cases, and held that the violation of a Coast Guard licensing regulation was negligence per se. This determination was based primarily on the Scindia Court's rejection of certain land-based tort law standards as inapplicable in section 905 (b) cases. ${ }^{115}$

In actions brouglit under general maritime law, particularly Kermarec v. Compagnie Generale Transatlantique, ${ }^{116}$ the Supreme Court has emphasized the inapplicability of the land-based status dis-

112. See supra text accompanying note 59.

113. See supra text accompanying notes 99-104.

114. 660 F.2d 933 (4th Cir. 1981) (per curiam), cert. denied, 102 S.Ct. 1442 (1982). See supra note 32 for a synopsis of the facts of the case.

115. The standards discussed by the Court are embodied in sections 343 and $343 \mathrm{~A}$ of the Restatement. See 451 U.S. at 168 n.14; Restatement (SECOND) OF TORTs 88343,343 A (1965). See supre note 26 for the text of sections 343 and 343A.

116. 358 U.S. 625 (1959). Kermarec was a suit for neghigence brought under the general maritime law by a plaintiff who was neither a seaman nor a longshoreman. In determining the standard of care owed by the shipowner to a visitor on board the vessel, the Kcrmarec Court rejected the land-based status distinctions between licensees and invitees as inappropriate in actions brought under the general maritime law:

The distinctions which the common law draws between licensee and invitee were inherited from a culture deeply rooted to the land, a culture which traced many of its standards to a heritage of feudalism .....

... For the admiralty law at this late date to import such conceptual distinctions would be foreign to its traditions of simplicity and practicality. . . The incorporation of such concepts appears particularly unwarranted when it is remembered that they originated under a legal system in which status depended almost entirely upon the nature of the individual's estate with respect to real property, a legal system in that respect entirely alien to the law of the sea.

Id at 629-32 (footnote omitted). 
tinctions embodied in Restatement (Second) of Torts Sections 343 and 343A. However, the Court's rejection of these same principles in Scindia was based not on a fundamental incompatability with principles of maritime law, but on a careful and thorough analysis of the legislative history of the 1972 amendments. ${ }^{117}$ The Scindia opinion emphasized that " $[t]$ he legislative history does not refer to the Restatement and also states that land-based principles of assumption of risk and contributory negligence are not to be applied in section 905(b) cases." 18 Thus the Scindia Court rejected Sections 343 and 343A of the Restatement not because they conflict with general principles of maritime law, but because they conflict with those particular aspects of maritime law applicable in section 905(b) negligence actions. Furthermore, the Supreme Court's decision in Scindia is consistent with a trend im land-based tort law toward a uniform standard of care. The Court noted that "even in land-locked jurisdictions, the trend is toward the abolition of status distmctions . . . and the adoption of the single duty of reasonable care under the circumstances."119 The Court's rejection of standards based on those distinctions should thus be viewed as a decision consonant with the development of land-based tort law, not as a directive to "break land" and return to maritime law.

\section{B. Policy Against Strict Liability in Section 905(b) Cases.}

Application of the concept of strict statutory liability to LHWCA cases is inconsistent not only with the relevant case law, but also with the clear intent of Congress in enacting section 905(b) to predicate vessel liability on the shipowner's actual negligence. Such an application would upset the delicate balance between vessel liability and the stevedore's duty of care under section 905(b), and frustrate the compromise effected by Congress in enacting the 1972 amendments to the

117. 451 U.S. at $164-72$.

118. Id. at 168 n.14; accord Johnson v. A/S Ivarans Rederi, 613 F.2d 334 (1st Cir. 1980), cert. denied, 449 U.S. 1135 (1981).

Since a rigid application of sections 343 and $343 \mathrm{~A}$ is generally more favorable to the vessel than the previous maritime negligence rule because of the presence of status distinctions and connotations of assumption of the risk and contributory negligence, those sections should not be made the basis of the standard of care without an explicit indication that Congress so intended.

613 F.2d at 349.

119. 613 F.2d at 349 (footnote omitted); see, e.g., Smith v. Arbaugh's Restaurant, 469 F.2d 97 (D.C. Cir. 1972), cert. denied, 412 U.S. 939 (1973); Rowland v. Cliristian, 69 Cal. 2d 108, 443 P.2d 561, 70 Cal. Rptr. 97 (1968); Mile High Fence Co. v. Radovich, 175 Colo. 537, 489 P.2d 308 (1971) (en banc); Pickard v. Honolulu, 51 Haw. 134, 452 P.2d 445 (1969); Ouellette v. Blanchard, 116 N.H. 552, 364 A.2d 631 (1976); Basso v. Miller, 40 N.Y.2d 233, 352 N.E.2d 868, 386 N.Y.S.2d 564 (1976); Mariorenzi v. Joseph DiPonte, lnc., 114 R.1. 294, 333 A.2d 127 (1975). 
LHWCA. ${ }^{120}$ The section 905(b) denial of the shipowners' right to indemnity from stevedores was balanced by limiting the shipowners' hability for negligence. Because tlie courts have strictly interpreted section $905(\mathrm{~b})$ in refusing shipowners indemnity from partially neghgent stevedores, ${ }^{121}$ fairness requires that the courts be equally strict in requiring that vessels be liable only for their own negligence.

It is therefore important that the vessel's negligence be determined according to traditional concepts of land-based tort law, not strict liability. To base vessel liability on a form of absolute statutory dutywhether derived from OSHA regulations, Coast Guard regulations, or both-would cause shipowners to be legally negligent in a much greater percentage of cases, and require the shipowner to pay for the stevedore's fault as well as its own. Because OSHA and Coast Guard regulations are multitudinous, a violation would probably be found in a large percentage of personal injury cases. Finally, because the plaintiff would have an increased likelihood of recovery under a standard of strict statutory liability, the number of section 905(b) cases would increase-an effect that the 1972 amendments were intended to alleviate. 122

\section{CONCLUSION}

In cases decided subsequent to the enactment of the 1972 amendments to the LHWCA, courts have shown a reluctance to hold a shipowner-negligent on the basis of a breach of statutory duty. Nonetheless, a few have held the shipowner negligent because of its

120. See Canizzo v. Farrell Lines, 579 F.2d 682, 687 (2d Cir.) (Friendly, J., dissenting), cert. denied, 439 U.S. 929 (1978); Hurst v. Triad Shipping Co., 554 F.2d 1237, 1246-48 (3d Cir.), cert. denied, 434 U.S. 861 (1977); Napoli v. [Transpacific Carriers, Etc.] Hellenic Lines, 536 F.2d 505, 506-07 (2d Cir. 1976); Bess v. Agromar Line, 518 F.2d 738, 740-41 (4th Cir. 1975); Ramirez v. Toko Kaiun K.K., 385 F. Supp. 644, 650-52 (N.D. Cal. 1974); Lucas v. "Brinknes" Schiffahris Ges., 379 F. Supp. 759, 767 (E.D. Pa. 1974) (specially convened three-judge panel), appeal dismissed, No. 75-1223 (3d Cir., April 30, 1975), cert. denied, 423 U.S. 866 (1975).

121. This is particularly true in light of the recent Supreine Court decision in Edinonds v. Compagnie Generale Transatlantique, 443 U.S. 256 (1979). In Edmonds, a section 905(b) case, the jury determined that the plaintiff was $10 \%$ at fault, the stevedore $70 \%$ at fault, and the shipowner $20 \%$ at fault. The trial court reduced the plaintiff's award by the $10 \%$ attributed to his own negligence but refused further to reduce the award against the shipowner in proportion to the fault of the stevedore. The Supreme Court affirmed the ruling of the district court, holding that the 1972 amendments to the LHWCA prohibit the application of a proportionate-fault rule in section 905(b) cases. See also Davis v. Partenreederei M.S. Normannia, 657 F.2d 1048 (9th Cir. 1981); Zapico v. Bucyrus-Erie Co. 579 F.2d 714 (2d Cir. 1978); Samuels v. Empresa Lineas Maritimas Argentinas, 573 F.2d 884 (5th Cir. 1978), cert. denied, 443 U.S. 915 (1979); Dodge v. Mitsui Shintaku Ginko K. K. Tokyo, 528 F.2d 669 (9th Cir. 1975), cert denied, 425 U.S. 944 (1976); - Shellman v. United States Lines, 528 F.2d 675 (9th Cir. 1975), cert. denied. 425 U.S. 936 (1976). 122 See supra note 20. 
violation of a Coast Guard or an OSHA regulation. In those cases the courts carefully adhered to the principles of land-based tort law found in Sections 286 and 288 of the Restatement (Second) of Torts and synthesized by the Fifth Circuit in Marshall. ${ }^{123}$

The Supreme Court's recent decision in Scindia does not modify this existing body of case law. In Scindia the Court placed definite limits on the duty of the shipowner, applying a standard of care based not on maritime standards but rather on the land-based concept of reasonable care under the circumstances. ${ }^{124}$ Thus, Scindia should not be construed to require the apphication of maritime concepts of strict statutory hability in section 905 (b) cases involving violations of OSHA or Coast Guard regulations. Decisions adopting such a standard are contrary to the intent and purpose of section $905(\mathrm{~b})$.

Kaye A. Pfister

123. See supra text accompanying note 59.

124. See supra text accompanying notes 105-19. 